\title{
Peptic Hydrolysis of Gluten, Glutenin and Gliadin from Wheat Grain: Kinetics and Characterisation of Peptides
}

\author{
Philippe Masson, Daniel Toméa and Yves Popineau \\ Institut National de la Recherche Agronomique, Laboratoire de Biochimie et Technologie des Protéines, \\ Rue de la Géraudière, 44072 Nantes Cedex, France and aInstitut National de la Santé et de la Recherche \\ Médicale, Unité 290, Hopital Saint-Lazare, 107 rue du Faubourg Saint-Denis, 75010 Paris, France
}

(Manuscript received 19 February 1986)

\begin{abstract}
The kinetics of the hydrolysis of gluten, glutenin and gliadin by pepsin was studied by following the reaction of the hydrolysate with ninhydrin and by SDS-gel electrophoresis. Glutenin was more rapidly hydrolysed than native molecules of gliadin and produced components of different size. The first stage of hydrolysis of gliadin resulted in the formation of fragments mainly in the range 25000 and 10000 daltons whereas polypeptides generated from glutenin had subunits of molecular weight (MW) in the range 65000,30000 and 10000 . Further hydrolysis resulted in the formation of subunits of MW around 24000 and 14000 for glutenin and gliadin respectively. The final stage of hydrolysis produced a quantity of peptides of MW under 10000 and a small quantity of free amino acids. No obvious differences in the molecular weights of the polypeptides released were found when the enzyme to gliadin ratio was varied. Components obtained from glutenin and gliadin were further characterised after gel filtration on Sephadex G50. Large polypeptides derived from both gliadin and glutenin contained large amounts of proline and glutamate. Surface hydrophobicity of derived components were different, and inferior to, those of the reduced glutenin and native gliadin. Reduction of disulphide bonds of digested polypeptides of glutenin showed the existence of peptides branched by interchain disulphide bonds. Peptic cleavage sites were probably located differently in glutenin and gliadin molecules.
\end{abstract}

Keywords: Hydrolysis; pepsin; gluten; glutenin; gliadin; peptides.

\section{Introduction}

Enzymic hydrolysis of proteins seems to be a valuable method for the preparation of polypeptides and peptides with new functional and biological properties. ${ }^{1,2}$ Hydrolysates as well as dietary protein have been shown to be of interest as a source of $\mathrm{N}$ in chemically-defined elemental diets. ${ }^{3}$

Enzymic hydrolysis of wheat protein has been used to investigate flour quality in relation to its physical properties ${ }^{4}$ both in order to characterise free amino acids contents for nutritional experiments, ${ }^{5-8}$ and to gain a better knowledge of the structure of gliadin and glutenin ${ }^{9-12}$ or at least to compare partial amino acid sequences of wheat proteins with those of other cereals. ${ }^{13}$ Other studies concerning enzymic digestions of gluten concentrated on isolating active peptides which may be toxic in coeliac disease. ${ }^{14-16}$ Because of reports linking wheat gluten digestion with mental disorders $\mathrm{s}^{17,18}$ purified peptides from peptic digests of wheat gluten were tested for opioid-like activity. ${ }^{19,20}$ Few reports are concerned with the precise description of components produced by enzymic hydrolysis of wheat proteins and modification of these proteins in order to obtain new functional properties.

Among proteinases, porcine pepsin is known to have a broad side chain specificity ${ }^{21}$ and to produce large polypeptides from wheat proteins. ${ }^{12,22}$ In order to gain a better understanding of the different components resulting from the peptic digestion of wheat proteins, their two main fractions, glutenin and gliadin, were digested by pepsin under controlled conditions and the resulting components were analysed by different techniques. The results obtained would give some information on 
how to prepare polypeptides and peptides possessing various functional characteristics according to their molecular weights, amino acid composition and hydrophobicity.

\section{Experimental}

\subsection{Preparation of wheat protein fractions}

Partially defatted gluten of common wheat Triticum aestivum (cv. Capitole) was prepared according to Popineau. ${ }^{23}$ Crude gliadin was extracted from gluten by solubilisation in a water-dioxane solvent (40:60 by vol). Crude gliadin and glutenin (the undissolved material) were directly freeze-dried.

The purified gliadin fraction was prepared by large-scale gel filtration on Ultrogel Aca 34 (column diam. $10 \mathrm{~cm}$, height $77 \mathrm{~cm}$, sample size $5 \mathrm{~g}$ ) equilibrated with $0.1 \mathrm{~m}$ acetic acid, $2 \mathrm{M}$ urea, $0.05 \mathrm{M} \mathrm{KCl}$, $\mathrm{pH} 3.3$ at a flow rate of $300 \mathrm{ml} \mathrm{h}^{-1}$ (Figure 1). Excluded peak 1 accounted for $38.8 \%$ of the total protein representing soluble glutenins. Peak 2 consisted of gliadin and accounted for $47.1 \%$ of recovered proteins. The fractions corresponding to this peak were pooled and constituted purified gliadin. Peak 3 containing albumins and globulins and non-protein components was discarded. The entire gliadin fraction was dialysed against distilled water and freeze-dried.

The protein content $(\mathrm{N} \times 5.7)$ of the defatted gluten, the purified gliadin and the crude glutenin were $82.3,93.1$ and $70.1 \%$ of dry matter respectively.

For peptic digestion, protein fractions $(750 \mathrm{mg})$ were dispersed in $21 \mathrm{ml} 0.1 \mathrm{M}$ acetic acid adjusted to $\mathrm{pH} 2$ with $1 \mathrm{M} \mathrm{HCl}$. Crystalline porcine pepsin (2000 FIP g $\mathrm{g}^{-1}$ : Merck) was added in the enzyme/substrate ratios: $1 / 20,1 / 33,1 / 50,1 / 100$ or $1 / 1000$ and the enzymic digestion carried out at $20^{\circ} \mathrm{C}$. Samples $(0.5 \mathrm{ml})$ were taken from the reaction batch at controlled times and mixed with $25 \mathrm{ml}$ $0.05 \mathrm{~m}$ phosphate buffer $\mathrm{pH} 7.2$ for the ninhydrin reaction of $1 \mathrm{ml}$ tris buffer $\mathrm{pH} 7.5(0.01 \mathrm{M}$ tris containing $1.6 \%$ SDS, $1 \% 2$-mercapto ethanol) for electrophoresis analysis. For analysis by gel filtration, the reaction was stopped by adjusting the hydrolysate to $\mathrm{pH} 7.2$ with concentrated ammonia.

\subsection{Chromatographic techniques}

Gel filtration experiments were performed on a Sephadex G50 column $(85 \times 2.5 \mathrm{~cm})$ equilibrated with $0.05 \mathrm{~m}$ ammonium acetate $\mathrm{pH} 7.2$ Hydrolysate sample $(10 \mathrm{ml})$ was centrifuged at $\mathrm{pH} 7.2$ to remove undisolved material before it was applied to the column. Column flow rate was $25 \mathrm{ml} \mathrm{h}^{-1}$. Fractions were detected simultaneously at $280 \mathrm{~nm}$ and $220 \mathrm{~nm}$, pooled, concentrated in vacuo and freeze-dried.

Reversed phase high-performance liquid chromatography (RP-h.p.l.c.) was performed using a Kontron h.p.l.c. 600 system monitored by a series 200 programmer. Hydrolysates were fractionated on a Spherisorb S5 ODS C18 (12.5 $\mathrm{cm} \times 4.9 \mathrm{~mm}$ i.d.) supplied by Kontron. An acetonitrile-water gradient (buffer A: $0.05 \%$ (by vol) trifluoroacetic acid (TFA); buffer B: $0.05 \%$ (by vol) TFA, $75 \%$

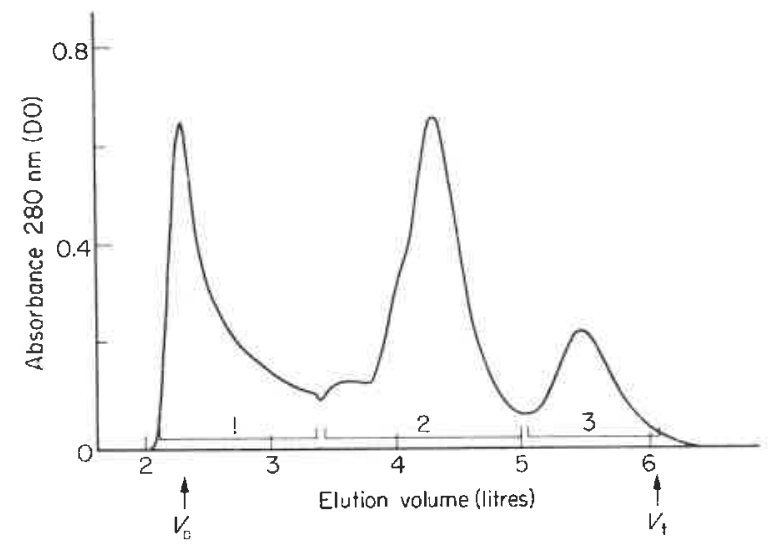

Figure 1. Fractionation of dioxane-water soluble proteins of gluten by gel filtration on Ultrogel ACA 34. The column was eluted with $0.1 \mathrm{M}$ acetic acid, $2 \mathrm{~m}$ urea, $0.05 \mathrm{M} \mathrm{KCl}$, $\mathrm{pH} 3.3$. 
(by vol) acetonitrile; $\mathrm{pH} 2.5$ ) was used for the elution of peptides from the RP column. Solvent B concentration was increased from 0 to $100 \%$ in $60 \mathrm{~min}(1.25 \% \mathrm{~B} \mathrm{~min}-1)$ at a flow rate of $1 \mathrm{ml} \mathrm{min}^{-1}$. Samples were dissolved in buffer $\mathrm{A}$ (concentration $5 \mathrm{mg} \mathrm{ml}^{-1}$ ) except for the native glutenin which was reduced by $5 \%$ (by vol) 2-mercaptoethanol in $8 \mathrm{M}$ urea, tris $0.05 \mathrm{~m}$ buffer, $\mathrm{pH} 7.6$, before being loaded on to the column. Proteins were detected at $214 \mathrm{~nm}$ with a Kontron Uvikon $730 \mathrm{LC}$ detector using 0.5 absorbance units full scale.

\subsection{Analytical methods}

For the ninhydrin reaction, $1 \mathrm{ml}$ of hydrolysate was mixed with $1 \mathrm{ml}$ of ninhydrin reagent in a reaction bath at $100^{\circ} \mathrm{C}$ for $30 \mathrm{~min}$. After cooling and centrifuging, $10 \mathrm{ml}$ ethanol-water solution (50:50, by vol) was added. Absorbance was recorded at $570 \mathrm{~nm}$. Leucine was used as a standard and the results expressed as leucine equivalents.

SDS-polyacrylamide gel electrophoresis (SDS-PAGE) was performed as described by Tome et al. ${ }^{24}$ but with a polyacrylamide gradient of $13-26 \%$ obtained by two solutions containing $13 \mathrm{~g}$ acrylamide plus $345 \mathrm{mg}$ of $\mathrm{NN}^{\prime}$ methylene bisacrylamide and $26 \mathrm{~g}$ acrylamide plus $690 \mathrm{mg}$ of $\mathrm{NN}^{\prime}$ methylene bisacrylamide each in $100 \mathrm{ml}$ of $0.5 \mathrm{M}$ tris buffer $\mathrm{pH} 6.8$ respectively.

Densitometric patterns were recorded on a Vernon recording densitometer.

Amino acid analyses were made on a Kontron Liquimat III amino acid analyser after sample hydrolysis $\left(1 \mathrm{mg} \mathrm{ml}^{-1}\right)$ in vacuo by $6 \mathrm{M} \mathrm{HCl}$ at $110^{\circ} \mathrm{C}$ for $24 \mathrm{~h}$. Sulphur amino acids were determined after performic acid oxidation to methionine sulphone and cysteic acid. ${ }^{25}$ Tryptophan was not determined.

\section{Results}

\subsection{Kinetics of hydrolysis}

The amount of free amino groups produced from gluten, glutenin and gliadin during peptic hydrolysis determined by reaction with ninhydrin are shown in Figure 2. Before hydrolysis gluten and glutenin fractions were only slightly soluble in hydrolysis buffer; a few seconds after addition of pepsin, they were readily solubilised indicating that peptic hydrolysis disrupted gluten and glutenin aggregates almost immediately generating molecules soluble at acid $\mathrm{pH}$. More total amino groups were released by glutenin than by gliadin, but with all samples, the digestion reached half completion in about $40 \mathrm{~min}$ and appeared to be almost complete after $200 \mathrm{~min}$. Increasing the pepsin to gluten ratio increased the total amount of free amino groups released (Figure 3).

SDS-PAGE patterns of purified gliadin peptic hydrolysates at various reaction times showed four major fractions A, B, C, D (Figure 4), the different composition of which can be seen from the

Figure 2. Production of terminal amino nitrogen during digestion of gluten, glutenin and gliadin fractions by pepsin (enzyme $/$ substrate $=1 / 33$ ) at $T=20^{\circ} \mathrm{C}$ and $\mathrm{pH}$ 2: (․ㅡ), glutenin; (ब), gluten; ( $\square$ ), gliadin.

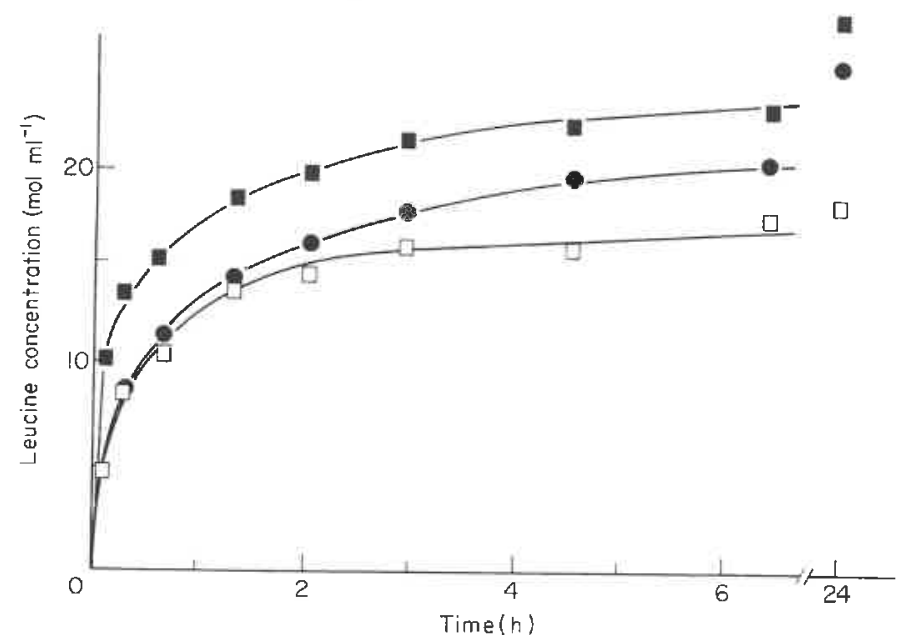




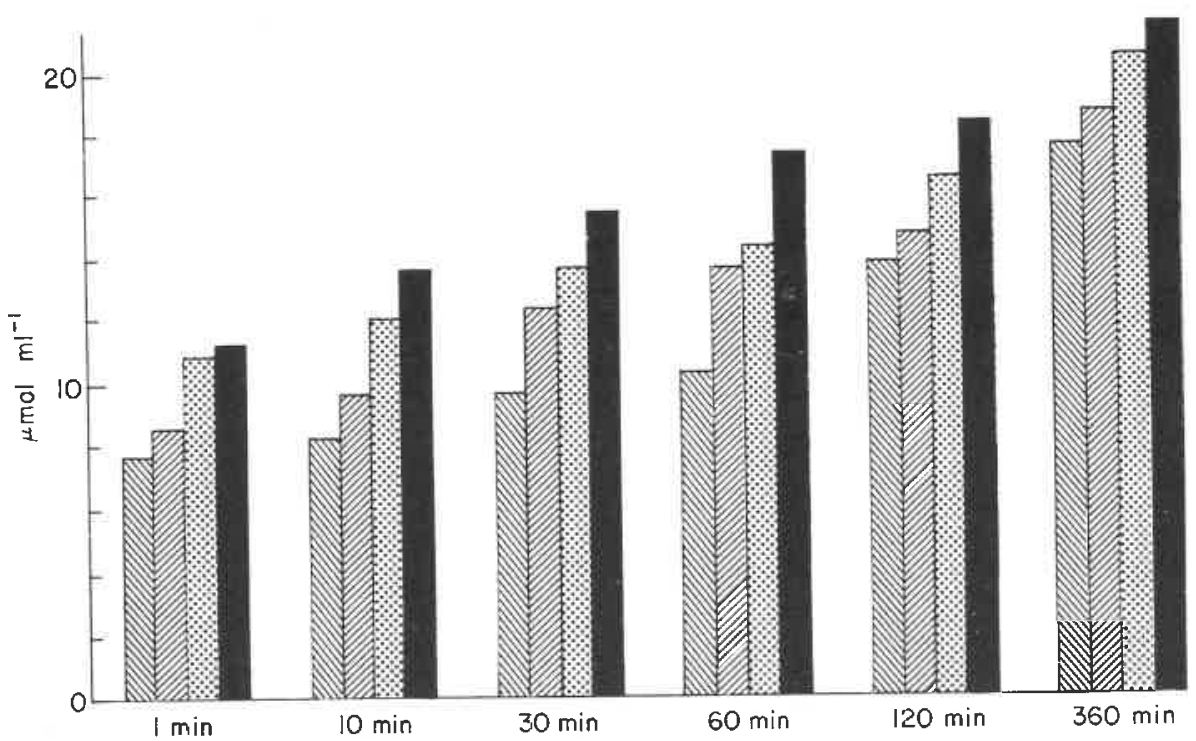

Figure 3. Influence of the concentration in pepsin [enzyme/substrate $=$ (団) $1 / 100$, (因) $1 / 50$, (间) $1 / 33$ and (E) $1 / 20$ ] on the amount of free amino groups produced from gluten. $T=20^{\circ} \mathrm{C}, \mathrm{pH} 2$.

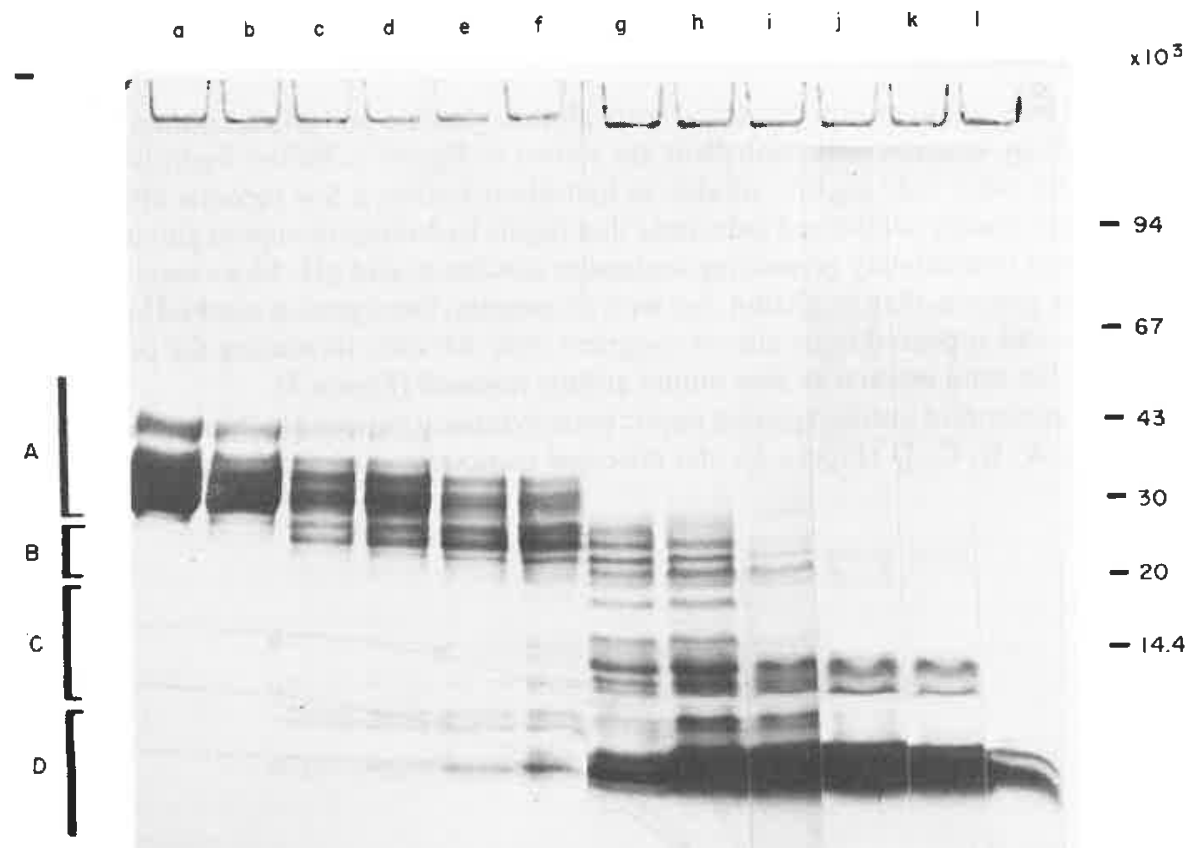

$10^{3}$

67

43

$-30$

20

14.4

$+$

Figure 4. SDS-PAGE pattern of gliadin fraction for various time intervals. a, No enzyme control; $b, 1 \mathrm{~min} ; \mathrm{c}, 3 \mathrm{~min} ; \mathrm{d}, 6 \mathrm{~min} ; \mathrm{e}$, $10 \mathrm{~min} ; \mathrm{f}, 15 \mathrm{~min} ; \mathrm{g}, 40 \mathrm{~min} ; \mathrm{h}, 60 \mathrm{~min} ; \mathrm{i}, 120 \mathrm{~min} ; \mathrm{j}, 260 \mathrm{~min} ; \mathrm{k}, 380 \mathrm{~min} ; 1,24 \mathrm{~h}$. Hydrolysis was done at $\mathrm{pH} 2$ and $T=20^{\circ} \mathrm{C}$ with an enzyme to substrate ratio of $1 / 33$. 

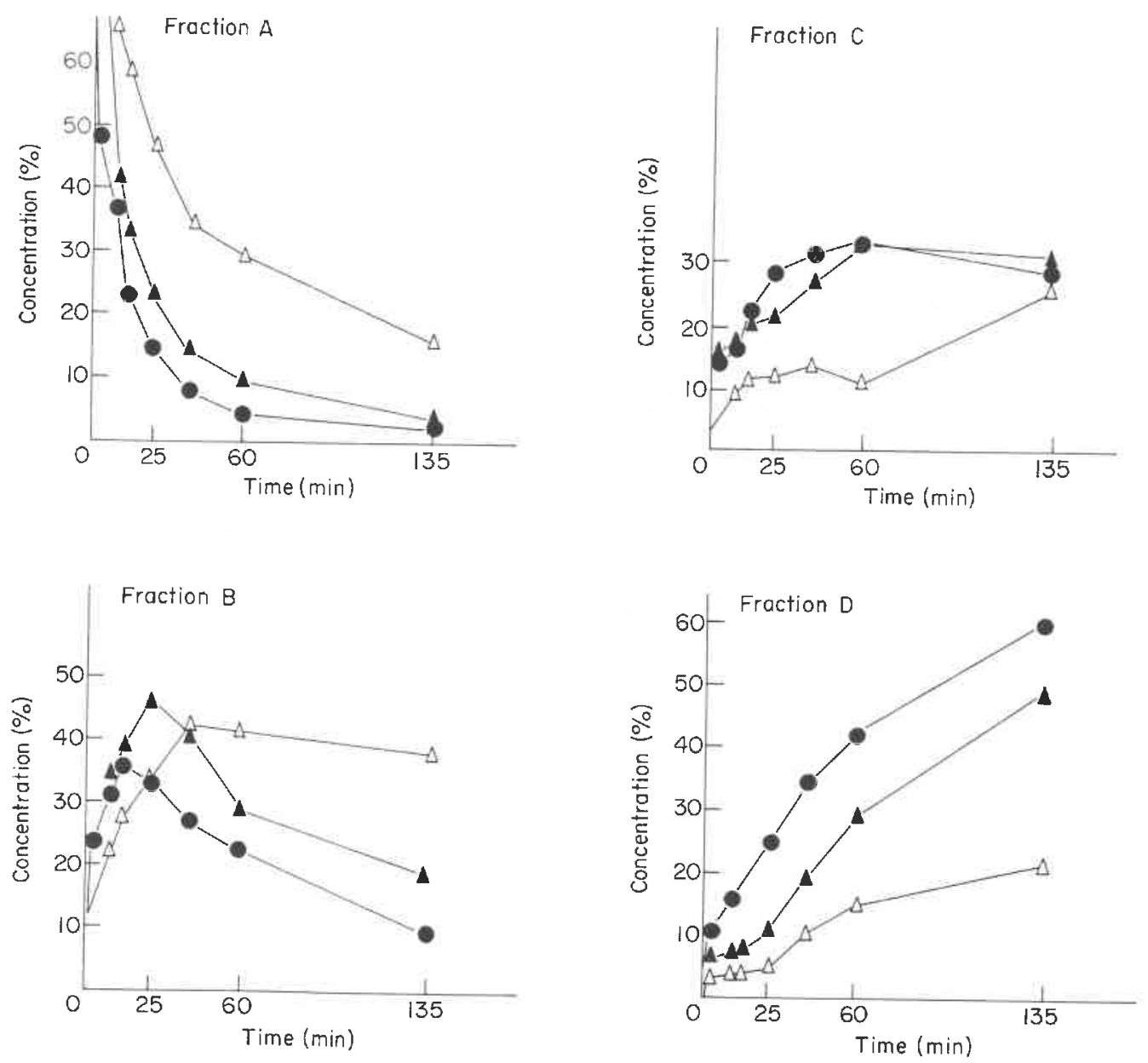

Figure 5. Variation with time of the different fractions resulting from an peptic hydrolysis of gliadin according to different enzyme to substrate ratios: $(-1 / 33 ;(\Delta), 1 / 100$ and $(\Delta), 1 / 1000$. Fraction $A$, native gliadin; fraction $B$, polypeptides in the range $28000-18000$; fraction $C$, polypeptides in the range $17500-12000$; fraction $D$, peptides $<12000$. Hydrolysis was done at
$\mathrm{pH}=2$ and $T=20^{\circ} \mathrm{C}$.

densitometric patterns for various enzyme/substrate ratios (Figure 5). Increasing the enzyme to gliadin ratio increased the speed of the disappearance native gliadins (fraction A) but not the qualitative aspects of the electrophoretic pattern. Fraction B, which consisted mainly of peptides of MW in the range $28000-20000$, reached a maximum between 15-45 min depending on the enzyme concentration. These components disappeared upon prolonged hydrolysates and resulted in peptides in the MW range 17 500-12 000 (fraction C) and lower than 9700 (fraction D).

SDS-PAGE patterns of glutenin peptic hydrolysates for various reaction times were more complex than those from gliadin (Figure 6), polypeptides appearing in the range 68000-65000, 3400023000 and $15000-9000$. Further hydrolysis produced subunits of molecular weights near 24000 , and after 320 min components with $\mathrm{MW}>15000$ completely disappeared.

\subsection{Fractionation of hydrolysates}

Peptic hydrolysis of purified gliadin and crude glutenin was carried out for $2 \mathrm{~h}$ at $20^{\circ} \mathrm{C}$ with an enzyme/substrate ratio of $1 / 33$, and the hydrolysates were chromatographed by gel filtration on Sephadex G50 column (Figure 7). Detection at $280 \mathrm{~nm}$ showed the presence of two major peaks for 


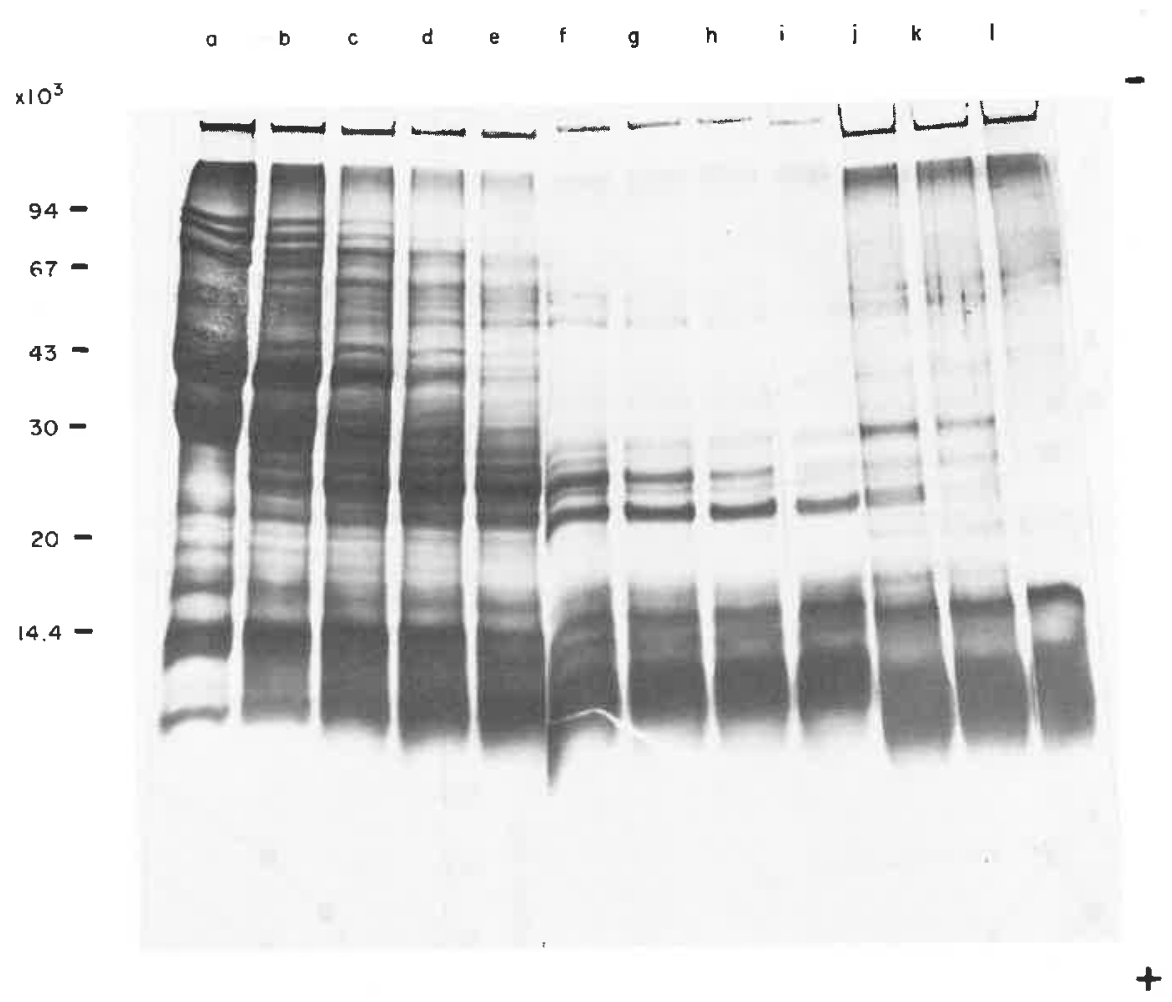

Figure 6. SDS-PAGE pattern of the glutenin fraction for various time intervals. a, non enzyme control; b, 1 min; c, 3 min; d, 6 $\min ; \mathrm{e}, 10 \mathrm{~min} ; \mathrm{f}, 25 \mathrm{~min} ; \mathrm{g}, 40 \mathrm{~min} ; \mathrm{h}, 60 \mathrm{~min} ; \mathrm{i}, 120 \mathrm{~min} ; \mathrm{j}, 260 \mathrm{~min} ; \mathrm{k}, 380 \mathrm{~min} ; 1,24 \mathrm{~h}$. Hydrolysis was done at $\mathrm{pH} 2$ and $T=20^{\circ} \mathrm{C}$ with an enzyme to substrate ratio of $1 / 33$.

gliadin hydrolysates (fraction 1 and 2) but only one for glutenin (fraction 1); however detection at $220 \mathrm{~nm}$ showed that both digests contained substances being continually eluted. These eluates were divided into six fractions which were then electrophoresed (SDS-PAGE) (Figures 8 and 9) and analysed for amino acid content (Table 1). The quantities of polypeptides recovered in each fraction, calculated from their amino acid contents, and their molecular weights obtained by gel filtration and SDS-PAGE are summarised in Table 2.

Fraction 1 of the gliadin hydrolysate comprised large polypeptides in the range 28 000-12 000 characterised by high contents of glutamate, proline and phenylalanine and smaller amounts of aspartate, sulphur containing amino acids, alanine, valine, isoleucine and leucine, compared to native gliadins. The relatively homogeneous fraction 2 , which represented $41.5 \%$ of the total digest, consisted of components in the MW range $12000-9000$. Fractions 3 and 4 which presented apparent MW in the ranges 7500-2700 and 2700-1400 respectively on Sephadex G50, seemed similar to those in fraction 2 by SDS-PAGE but were weakly stained. Fraction 5 contained small peptides with MW under 1000 and fraction 6 (with an elution volume equal to the total volume of the Sephadex G50 column) is characteristic of components interacting with the gel. Fractions 5 and 6 did not react with the stain used after SDS-PAGE. From the amino acid analysis, fraction 3 was characterised by a high proline content; fractions 4 and 5 had compositions very different to that of gliadin.

With glutenin digests, the non-reduced fraction 1 showed large polypeptides with $\mathrm{MW}$ between 25000 and 45000 not found in native glutenin, moreover only one band had a MW $<20000$. When the S-S bonds of fraction 1 were reduced many subunits $<20000$ and some $<14000$, were observed, only one band over 30000 remaining. The amino acid composition of fraction 1 did not differ largely from the undigested protein but there were increased contents of glutamate and proline and a slight decrease in the amount of methionine and cysteine. The non-reduced fraction 2 , characterised by the 

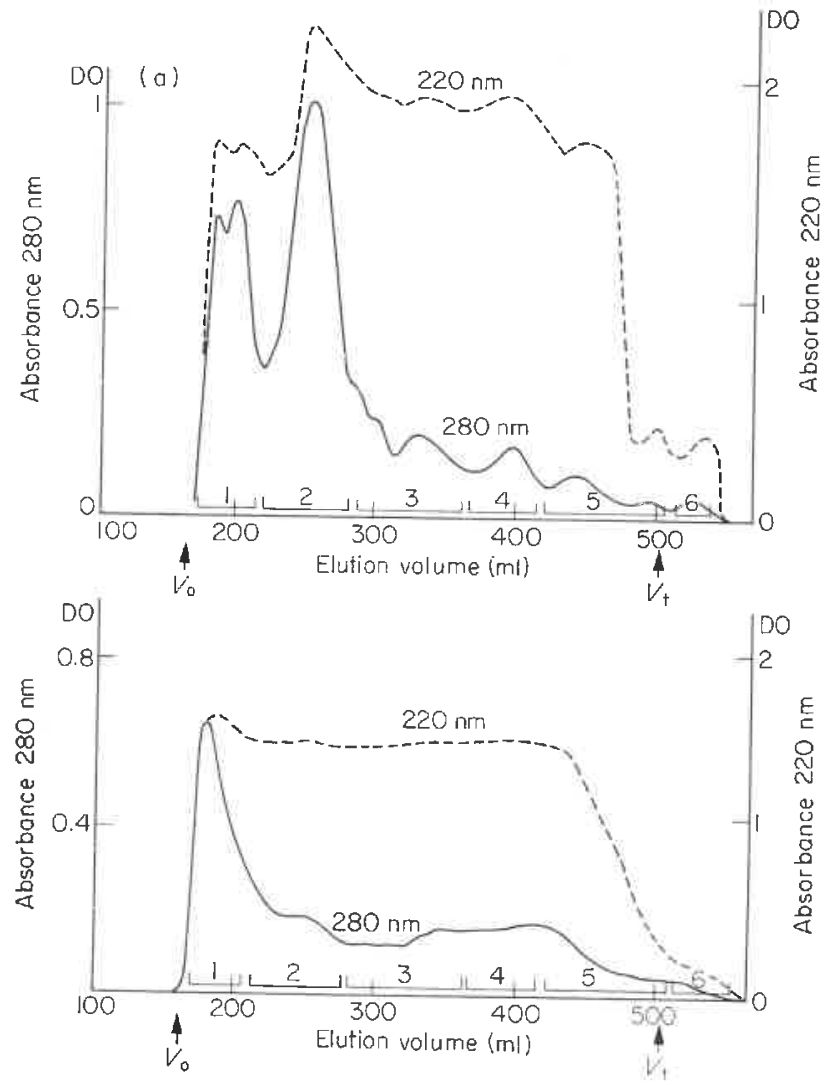

Figure 7. Chromatographic separations of peptic fragments from (a) gliadin and (b) glutenin fraction on a Sephadex G50 column. Conditions of digestion: $2 \mathrm{~h}$ at $T=20^{\circ} \mathrm{C}$ in an enzyme to substrate ratio of $1 / 33$.

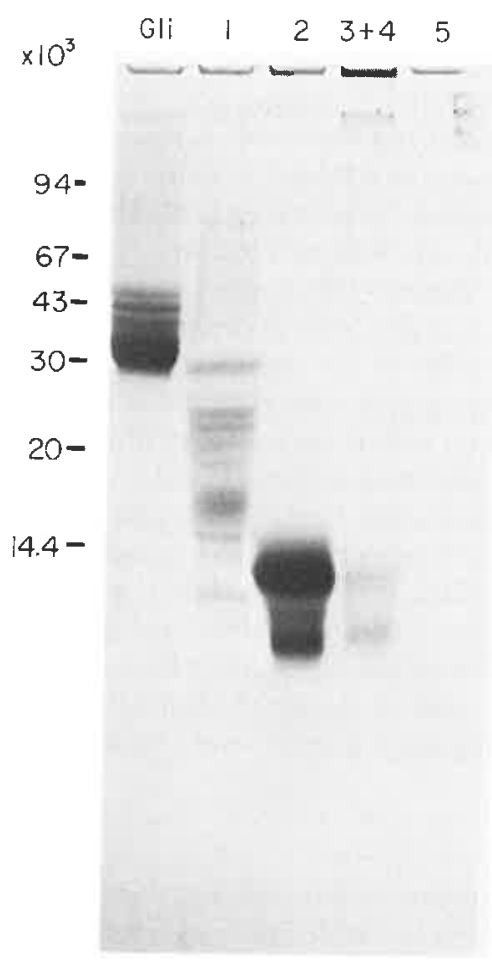

Figure 8. SDS-PAGE of the different fractions of gliadin ubtained after gel filtration on Sephadex G50. Gli: native gliadin. 

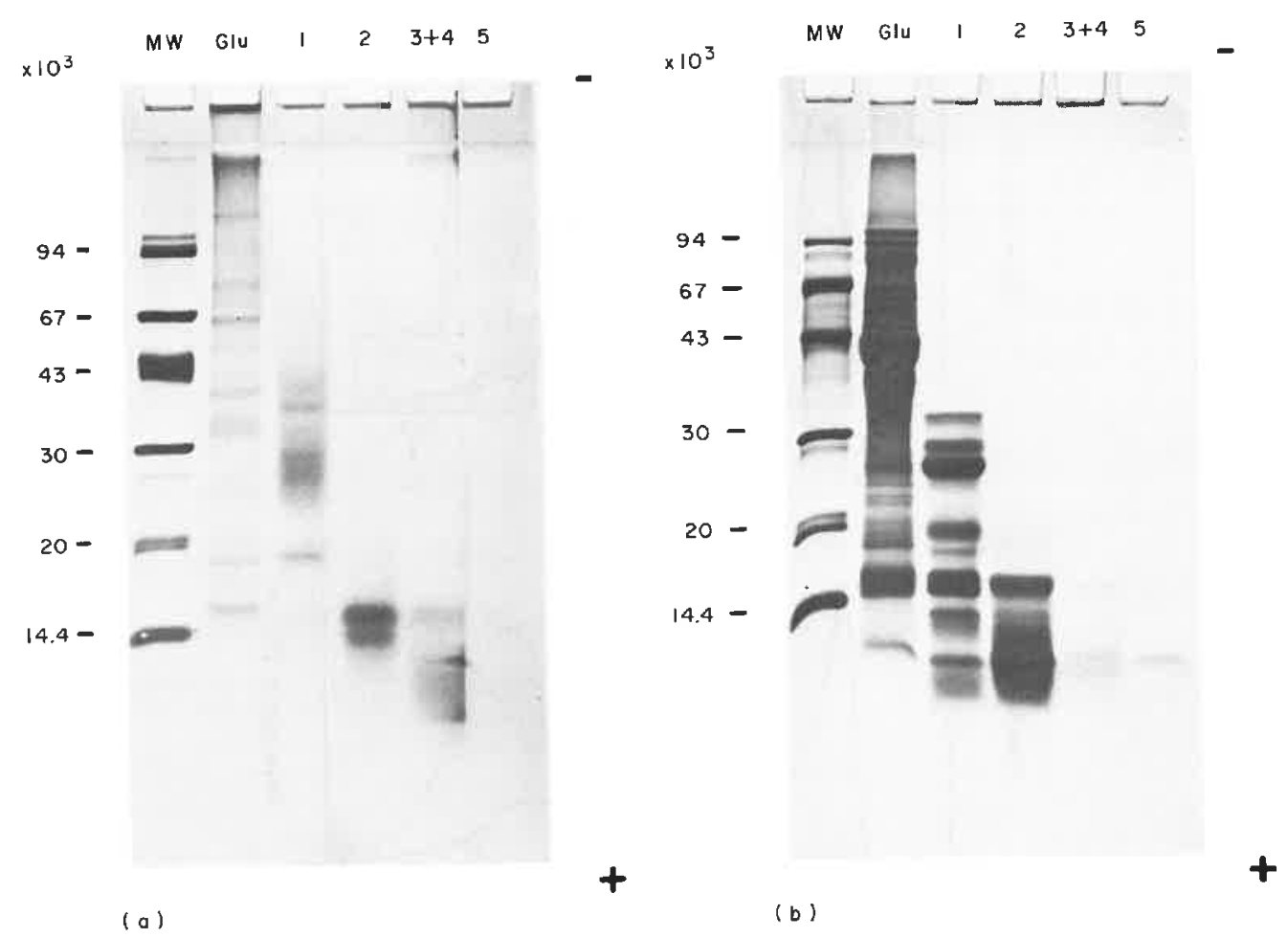

Figure 9. SDS-PAGE of (a) non reduced and (b) reduced fractions of glutenin obtained after gel filtration on Sephadex G50. Glu: native glutenin.

presence of two bands of approximately 15000 produces many peptides of $\mathrm{MW}<15000$ (Figures 9a and $9 \mathrm{~b}$ ); after reduction only one band around 15000 remained. The reduced and non-reduced fractions 3 and 4 possessed similar characteristics and fraction 5 stained only weakly.

Analysis by RP-h.p.l.c. of the six fractions from both the gliadin and glutenin digests separated by gel filtration on Sephadex G50 (Figure 10) showed the complexity of the fractions, even those which did not stain well. All fractions were soluble in TFA ( $0.05 \%$ (by vol) solution $\mathrm{pH} 2.5)$ except the native glutenin which was reduced before injection. According to their retention time on the C18 column no gliadin peptide displayed a surface hydrophobicity higher than that of native gliadin and as the MW of the peptides decreased, retention time also decreased. Furthermore, the peptide patterns appeared more complex, covering a larger range of hydrophobicities. The same pattern was observed with glutenin digest fractions. Fractions of a given molecular weight displayed the same range of hydrophobicity as the corresponding gliadin digest fraction, except for the first one eluted from Sephadex G50. This fraction, comprising the largest peptides was more heterogeneous in glutenin digests but less so in gliadin digests. Glutenin digest fraction 1 was composed of two groups of peptides, the first was eluted between 26.5 and $38.5 \%$ acetonitrile, and corresponded to the range of surface hydrophobicity of peptides contained in gliadin digest fraction 1 . The second group was eluted between $38.5 \%$ and $54 \%$ acetonitrile, and corresponded, as far as surface hydrophobicity was concerned, to the less hydrophobic glutenin subunits or native gliadin. But in contrast to native glutenin these peptides were readily soluble in $0.05 \%$ (by vol) TFA.

\section{Discussion}

The amount of free amino groups produced from gluten and its components, glutenin and gliadin, during peptic hydrolysis confirmed previous results that wheat proteins possessed peptic sensitive 
Table 1. Amino acid composition (as residues $\%$ ) of the different fractions after a gel filtration on Sephaden $G 50$-of an=peptic digest $\left(2 \mathrm{~h}, \mathrm{E} / \mathrm{S}=1 / 33, \mathrm{t}=20^{\circ} \mathrm{C}\right)$ of glutenin and gliadin.

\begin{tabular}{|c|c|c|c|c|c|c|}
\hline & & Fraction 1 & Fraction 2 & Fraction 3 & Fraction 4 & Fraction 5 \\
\hline \multicolumn{7}{|c|}{ Gliadin } \\
\hline Asp & 27 & 17 & 25 & 21 & 39 & 99 \\
\hline Thr & 16 & 27 & 15 & 9 & 12 & 27 \\
\hline Ser & 42 & 33 & 37 & 50 & 59 & 60 \\
\hline Glu & 427 & 455 & 453 & 462 & 408 & 273 \\
\hline Pro & 149 & 230 & 144 & 170 & 76 & 80 \\
\hline Gly & 16 & 17 & 11 & 25 & 41 & 64 \\
\hline Ala & 20 & 12 & 13 & 15 & 27 & 38 \\
\hline 1/2Cys & 28 & 12 & 28 & 10 & 31 & 29 \\
\hline Val & 37 & 16 & 33 & 36 & 42 & 33 \\
\hline Met & 17 & 4 & 14 & 5 & 30 & 7 \\
\hline Ile & 36 & 16 & 34 & 22 & 57 & 56 \\
\hline Leu & 70 & 39 & 63 & 61 & 100 & 85 \\
\hline Tyr & 20 & & 28 & 23 & 9 & 33 \\
\hline Phe & 46 & 84 & 54 & 55 & 14 & 26 \\
\hline Lys & 5 & 7 & 7 & 5 & 14 & 30 \\
\hline His & 21 & 15 & 19 & 15 & 15 & \\
\hline Arg & 23 & 16 & 22 & 16 & 28 & 60 \\
\hline \multicolumn{7}{|c|}{ Glutenin } \\
\hline Asp & 48 & 16 & 41 & 54 & 77 & 87 \\
\hline Thr & 31 & 23 & 23 & 25 & 37 & 31 \\
\hline Ser & 52 & 54 & 49 & 52 & 58 & 47 \\
\hline Glu & 328 & 419 & 346 & 302 & 227 & 139 \\
\hline Pro & 112 & 133 & 123 & 105 & 60 & 6 \\
\hline Gly & 40 & 50 & 33 & 47 & 52 & 55 \\
\hline Ala & 31 & 17 & 26 & 42 & 56 & 48 \\
\hline $1 / 2$ Cys & 27 & 23 & 25 & 11 & 3 & 9 \\
\hline Val & 41 & 30 & 50 & 53 & 62 & 51 \\
\hline Met & 22 & 16 & 14 & 13 & 9 & 18 \\
\hline Ile & 34 & 25 & 39 & 38 & 56 & 60 \\
\hline Leu & 69 & 56 & 78 & 78 & 95 & 62 \\
\hline Tyr & 31 & 34 & 26 & 30 & 28 & 132 \\
\hline Phe & 45 & 43 & 38 & 52 & 52 & 118 \\
\hline Lys & 25 & 10 & 16 & 30 & 38 & 33 \\
\hline His & 22 & 22 & 25 & 22 & 26 & 33 \\
\hline Arg & 42 & 29 & 48 & 46 & 64 & 71 \\
\hline
\end{tabular}

${ }^{a}$ Fraction 6 (representating $0.1 \%$ of the total digest) was not analysed.

bonds. ${ }^{4,6}$ Digestion was rapid with a five-fold increase of free amino groups in $2 \mathrm{~h}$ with gluten. When the enzyme to substrate ratio was increased free amino groups increased but in lower proportions.

Variation of the pepsin/gliadin ratio did not modify the nature of the peptides produced but altered the kinetics of the digestion process that took place sequentially. When the enzyme concentration was lowered to $1 / 1000$ or $1 / 100$ the appearance of fraction $\mathrm{D}$ was considerably retarded although fraction $\mathrm{A}$ was extensively degraded and fractions $\mathrm{B}$ and $\mathrm{C}$ had increased. Our interpreta-

Table 2. Weight distribution of polypeptides and peptides separated by gel filtration on Sephadex G50 of peptic digests of glutenin and gliadin $\left(\mathrm{E} / \mathrm{S}=1 / 33,2 \mathrm{~h}\right.$ at $\left.t=20^{\circ} \mathrm{C}\right)$ according to yield calculated from amino acid analysis

\begin{tabular}{|c|c|c|c|c|c|c|}
\hline & \multicolumn{6}{|c|}{ Fraction } \\
\hline & $1 \succ$ & 2 & 3 & 4 & 5 & 6 \\
\hline $\begin{array}{l}\text { Apparent range } \\
\text { of MW (daltons) }\end{array}$ & 18000 & $\begin{array}{c}18000 \\
- \\
7500\end{array}$ & $\begin{array}{l}7500 \\
- \\
2700\end{array}$ & $\begin{array}{l}2700 \\
- \\
1400\end{array}$ & $<1400$ & $\begin{array}{l}\text { Interaction } \\
\text { with gel }\end{array}$ \\
\hline Gliadin yield $(\%)$ & 20.8 & 41.5 & 31.0 & 4.4 & 22 & 0.1 \\
\hline Glutenin yield (\%) & 25.7 & 21.2 & 29.6 & 22.2 & 1.2 & 0.1 \\
\hline
\end{tabular}



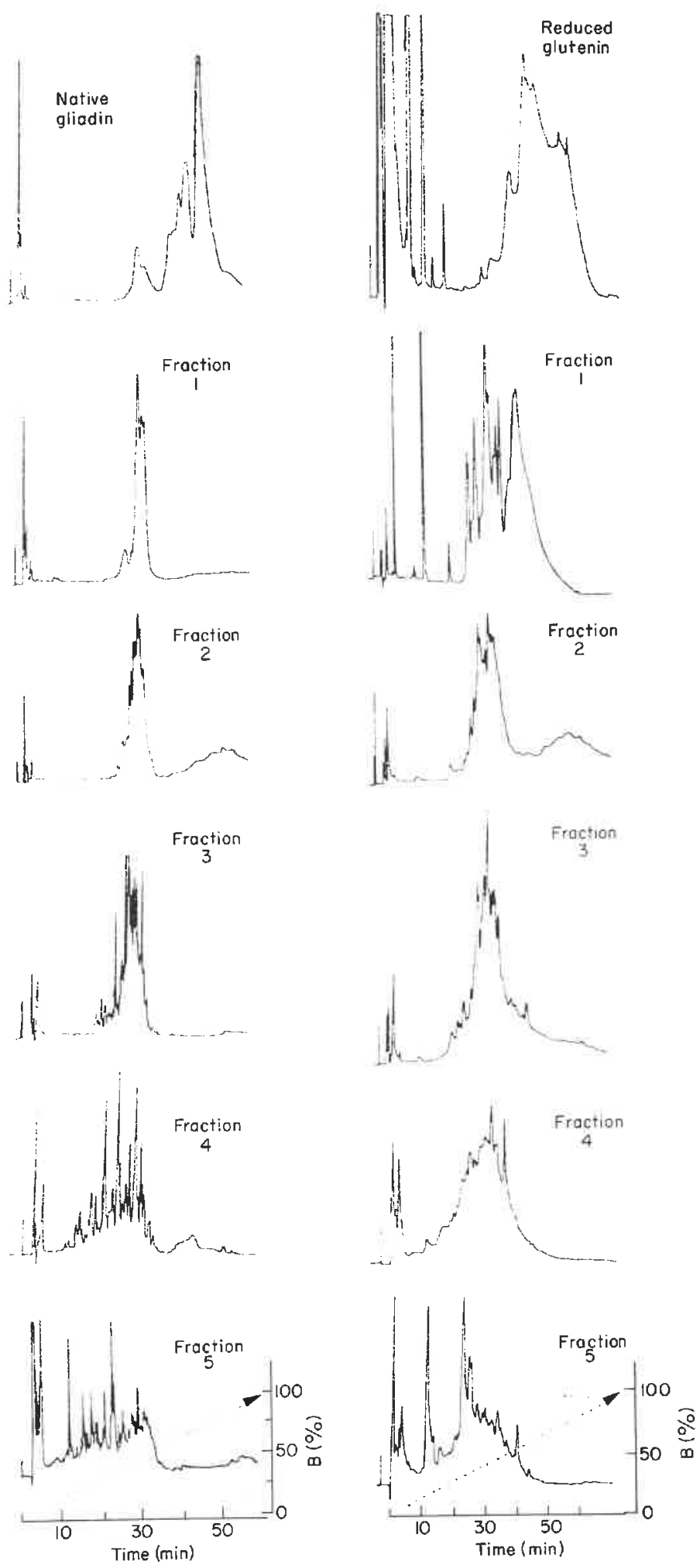

Figure 10. H.p.l.c. separations of peptic fractions from gliadin and glutenin fractions on an ODS reversed phase $\mathrm{C} 18$ column, after gel filtration on Sephadex G50 column. 
tion is that, during the first stage of hydrolysis gliadin proteins were cleaved essentially in two families of fragments: one of about 25000 (fraction B) and the other of approximatively 15000 (fraction C). However the largest increase of fraction $\mathrm{C}$ corresponded to a decrease of fraction $\mathrm{B}$, suggesting that fraction $\mathrm{C}$ also contained some degradation products of fraction $\mathrm{B}$. Lastly, fraction $\mathrm{D}$ corresponded to the small peptides coming from various hydrolysis steps of the other fractions.

Large polypeptides with MW in the range $28000-20000$ produced in the first stage can constitute up to $45 \%$ of gliadin digest after $45 \mathrm{~min}$. They were characterised by high contents of glutamate, proline and phenylalanine. Although this fraction was composed of peptides coming from several gliadin components, its composition was related to the amino acid sequence of the $\alpha / \beta$ type gliadins taken as reference proteins. ${ }^{26}$ Their sequence can be divided in domains, one of them (domain II) being characterised by a sequence repetition with high proline and glutamate contents whereas other domains contained lower amounts of proline. ${ }^{26}$ So it is probable that large peptides are derived from native gliadins by cleavage of the polypeptides chain in its $-\mathrm{COOH}$ terminal region because of proline enrichment and decreased cysteine content. Moreover a lower cysteine content suggests that cleavage occurred near the cys-cys. doublet (156-157). Cleavage at this site would generate a large peptide of MW 20000 and a smaller one around 13000.

The results here show that peptic hydrolysis of glutenin produced firstly large polypeptides in the range $68000-65000$ and $34000-23000$, which were rich in glutamate and proline, and were soluble in the different non-denaturing solvents used. Their formation was accompanied by a rapid solubilisation of samples and a decrease of the viscosity probably due to cleavage in interchain disulphide bond regions. ${ }^{6,10}$ This hypothesis, which disagrees with other published results, ${ }^{12}$ was strengthened in the present study by the observed presence of peptides containing interchain disulphide bonds.

The second stage of hydrolysis was characterised by the appearance of components of MW around 15000 for gliadin and 24000 for glutenin and having amino acid compositions similar to those of the native proteins. Some of the subunits derived from glutenin were also $S-S$ branched peptides.

The final stage of hydrolysis produced peptides of $M W<10000$. Degradation of these small peptides cannot be described with precision because of the complexity of the mixture. They could represent an important part, nearly $50 \%$, of the digest in the case of prolonged hydrolysis. The free amino acids were present in low concentration and accounted for less than $1.2 \%$ and $3.2 \%$ for gliadin and glutenin digests respectively. Average molecular weights of 1150 daltons for glutenin peptides and 1990 for gliadin peptides were calculated after complete hydrolysis of the sample. ${ }^{10}$

Glutenin and gliadin digests fractions were composed of polypeptides differing in molecular weight, amino acid composition, surface hydrophobicity and structure. These results confirmed previous observations of differences in polypeptide size. ${ }^{10}$ This might be due either to differences in amino sequences of gliadin and glutenin, or in protein conformation. These results showed that differences of site location, structure and conformation could explain differences in hydrolysis and of peptide characteristics previously described. ${ }^{10-12}$ Production of large peptides in the early stage of gliadin digestion suggests that most of peptic cleavage sites were not accessible in the native molecule. Conversely the initial digestion of glutenin leads to a rapid decrease of the molecular weight of components. Moreover, according to the kinetics data, glutenin was hydrolysed more rapidly than gliadin. After $10 \mathrm{~min}$ (enzyme/substrate=1/33) intact glutenin subunits had totally disappeared, whereas up to $20 \%$ of native gliadins were still present. Thus hydrolysis sites were probably more accessible to enzyme attack in glutenin than in native gliadin. These results can be related to viscosimetric studies that showed that at pH 2.9-9.0 in $0.1 \mathrm{M}$ acetic acid a gliadin molecule retained a certain degree of compactness although a part of the molecule was probably expanded. Conversely if the structure of glutenin in those conditions is of that proposed by Tatham et al. ${ }^{27}$ these macromolecules could be more accessible to peptic digestion.

It has been previously reported ${ }^{12,22}$ that pepsin-sensitive bonds are principally located in terminal regions of polypeptide chains. Those findings were confirmed here with gliadins at the first stage of digestion where results indicated that only a part of $-\mathrm{COOH}$ terminal region was cleaved. Modification of SDS-PAGE pattern of glutenins after reduction (Figure 9) indicated the presence of the disulphide branched polypeptides in the hydrolysate. As it has been shown that most cysteine 
residues are located very near the $-\mathrm{COOH}$ and $-\mathrm{NH} 2$ terminal ends of chains, ${ }^{28-32}$ peptic cleavage might not occur in the very terminal region of subunits because $S-S$ reduction of branched peptides leads to a decrease of their MW from 40000 to 20000.

As the complexity of native protein samples and of peptidic patterns hindered definite conclusions about the sequential appearance of peptides and location of hydrolysis sites, and also renders peptide purification difficult for biochemical and functional characterisation, studies are in progress on highly purified gliadin components.

\section{References}

1. Lee, J. W.; Lopez, A. Modification of plant proteins by immobilised proteases. CRC. Crit. Rev. Food Sci. Nutr. 1984, 21, $289-322$.

2. Brantl, V.; Teschemacher, H. A material with opioid activity in bovine milk and milk products. Naunyn-Schmied. Arch. Pharmacol. 1979, 306, 301-304.

3. Silk, D. B. A.; Grimble, G. K.; Rees, R. G. Protein digestion and amino acid and peptide absorption. Proc. Nutr. Soc. $1985,44,63-72$.

4. Verma, S. C.; McCalla, A. G. Enzymatic hydrolysis of dispersed wheat gluten. Cereal Chem. 1966, 43, 28-34.

5. Galinska, Z.; Kaczkowski, J. Electrophoretic investigations of proteolysis products of wheat gluten. Acta Aliment. Pol. $1977,3,379-387$.

6. Oka, S.; Babel, F. J.; Drandt, H. N. Proteolytic action of pepsin on glutenin. J. Food Sci. 1965, 30, $212-217$.

7. Matoba, T.; Dai, E.; Yonezawa, D.; Oste, R.; Nair, B. M. An approach to assessing the gastro-intestinal digestion of rice and wheat proteins: use of a model system with pepsin, pancreatin and intracellular peptidases. Agric. Biol. Chem. 1982, 46, 465-472.

8. Friedrich, M.; Noack, J.; Proll, J.; Noack, G. Absorption of enzymatic protein hydrolysate on their equimolar mixtures of free amino acids in the perfused small intestine of rats. Biomed. Biochim. Acta 1984, 43, 117-128.

9. Finlayson, A. J. The compositions of some peptides produced by an enzymic hydrolysis of wheat gliadin. Can. J. Biochem. $1964,42,1133-1140$

10. Bietz, J. A.; Rothfus, J. A. Composition of peptides from wheat gliadin and glutenin. Cereal Chem. 1970, 47, 381-392.

11. Bietz, J. A.; Huebner, F. R.; Rothfus, J. A. Chromatographic comparisons of peptic digests of individual gliadin proteins. Cereal Chem. 1970, 47, 393-404.

12. Danno, G.; Natake, M. Susceptibility of wheat glutenin to enzymatic hydrolysis. Agric. Biol. Chem. $1980,44,2155-2159$.

13. Wieser, H.; Seilmeier, W.; Belitz, H. D. Comparative investigations of partial amino acid sequences of prolamines and glutelins from cereals. VI. Anion exchange chromatography of peptide fractions obtain by cation exchanges chromatography. Z. Lebensm. Unters. Forsch. 1984, 178, 173-178.

14. Cornell, H. J.; Maxwell, R. J. Amino acid composition of gliadin fractions which may be toxic to individuals with coeliac disease. Clin. Chim. Acta 1982, 123, 311-322.

15. Jos, J.; Tand, M. F.; Arnaud-Battandier, F.; Boissel, J. P.; Popineau, Y.; Wajcman, H. Separation of pure toxic peptides from beta-gliadin subfraction using high performance liquid chromatography. Clin. Chim. Acta 1983, 134, $189-198$.

16. Wieser, H.; Belitz, H. D.; Ashkenazi, A.; Idar, D. Isolation of coeliac active peptide fractions from gliadin. Z. Lebensm. unters. Forsch. 1983, 176, 85-94.

17. Singh, M. M.; Kay, S. R. Wheat gluten as a pathogenic factor in schizophrenia. Science 1976, 191, $401-402$.

18. Dohan, F. C. The possible pathogenic effect of cereal grains in schizophrenia. Acta Neurol. (Naples) 1976, 31, 195-205.

19. Zioudrou, C.; Streaty, R. A.; Klee, W. A. Opioid peptides derived from food proteins: the exorphins. J. Biol. Chem. 1979, 25, 2446-2449.

20. Huebner, F. R.; Lieberman, R. W.; Rubino, R. P.; Wall, J, S. Demonstration of high opioid like activity in isolated peptides from wheat gluten hydrolysates. Peptides 1984, 5, $1139-1147$.

21. Fruton, J. S. Specificity and mechanism of pepsin action on synthetic substrates. In: Acid Proteases: Structure, Function and Biology (Tang, J., Ed.), Plenum Press, 1977, p. 131.

22. Yang, H. J.; McCalla, A. G. Action of proteolytic enzymes on wheat gluten. Can. J. Biochem. 1968, 46, 1019-1022.

23. Popineau, Y. Fractionation of acetic acid soluble proteins from wheat gluten by hydrophobic interaction chromatography: evidence for different behaviour of gliadin and glutenin proteins. J. Cereal Science 1985, 3, 29-38.

24. Tome, D.; Dhoye, C.; Gaborit, T.; Kozlowski, A.; Valdebouze, P. Isolation and separation of trypsir inhibitors and haemagglutinins in some legume seeds (Pisum sativum L.). Sciences des Aliments 1981, 1, 587-560.

25. Moore, S. On the determination of cystine as cysteic acid. J. Biol. Chem. 1963, 238, 235-237.

26. Kasarda, D. D.; Okita, T. W.; Bernardin, J. E.; Baecker, P. A.; Nimmo, C. C.; Lew, E. J. L.; Dietler, M. D.; Greene, F. C. Nucleic acid (CDNA) and amino acid sequences of alpha-type gliadins from wheat (Triticum aestivum). Proc. Natl. Acad. Sci. USA 1984, 81, 4712-4716.

27. Tatham, A. S.; Shewry, P. R.; Miflin, B. J. Wheat gluten elasticity a similar molecular basis to elastin? FEBS Lett. 1984, 177, 205-208.

28. Forde, J.; Forde, B. G.; Fry, R. P.; Kreis, M.; Shewry, P. R.; Miflin, B. J. Identification of barley and wheat CDNA clones related to the high Mr polypeptides of wheat gluten. FEBS Lett. 1983, 163, 360-366.

29. Shewry, P. R.; Field, J. M.; Faulks, A. J.; Parmar, S.; Miflin, B. J.; Dietler, M. D.; Lew, E. J. L.; Kasarda, D. K. The purification and $N$-terminal amino acid sequence analysis of the high molecular weight gluten polypeptides of wheat Biochim. Biophys. Acta 1984, 788, 23-34. 
30. Field, J. M.; Shewry, P. R.; Miflin, B. J.; March, J. F. The purification and characterization of homologous high molecular weight storage proteins from grain of wheat, rye and barley. Theor. Appl. Genet. 1982, 62, 330-336.

31. Moonen, J. H. E.; Scheepstra, A.; Graveland, A. Biochemical properties of some high molecular weight susbunits of wheat glutenin. J. Cereal Sci. 1985, 3, 12-27.

32. Thompson, R. D.; Bartels, D.; Harberd, N. P.; Flavell, R. B. Characterization of the multigene family coding for HMW glutenin subunits in wheat using CDNA clones. Theor. Appl. Genet. 1983, 67, 87-96. 
